NASA Technical Memorandum 106057

\title{
Characteristics of Linearly Tapered Slot Antenna With CPW Feed on High Resistivity Silicon
}

Rainee N. Simons

Sverdrup Technology, Inc.

Lewis Research Center Group

Brook Park, Ohio

and

Susan R. Taub and Richard Q. Lee

National Aeronautics and Space Administration

Lewis Research Center

Cleveland, Ohio

Prepared for the

1993 IEEE AP-S International Symposium and URSI Radio Science Meeting sponsored by the IEEE and USNC Commissions A, B, D, and F Ann Arbor, Michigan, June 27-July 2, 1993 


\title{
CHARACTERISTICS OF LINEARLY TAPERED SLOT ANTENNA WITH CPW FEED
}

\section{ON HIGH RESISTIVITY SILICON}

\author{
Rainee N. Simons \\ Sverdrup Technology, Inc. \\ Lewis Research Center Group \\ Brook Park, Ohio 44142 \\ -and \\ Susan R. Taub and Richard Q. Lee \\ National Aeronautics and Space Administration \\ Lewis Research Center \\ Cleveland, Ohio 44135
}

\section{SUMMARY}

A linearly tapered slot antenna (LTSA) has been fabricated on a high resistivity silicon substrate and tested at C-Band frequencies. The LTSA is electromagnetically coupled to a coplanar waveguide (CPW) feed. In this paper, the measured radiation patterns, gain and return loss are presented and discussed.

\section{INTRODUCTION}

Linearly tapered slot antennas (LTSA's) have many exceptional features such as narrow beamwidth, high element gain, wide bandwidth and small transverse spacing between elements in an array. These features make them attractive in satellite communication antennas (ref. 1). Previously reported LTSA antennas are fabricated on low dielectric constant RT-5880 Duroid substrate (refs. 2 to 4). This paper describes the design and performance of a LTSA constructed on a high resistivity silicon substrate. By choosing a silicon substrate with sufficiently high resistivity it is possible to make the dielectric attenuation constant of the microwave transmission line for the feed network approach that of GaAs (ref. 5). Compared to designs presented earlier, the new design has smaller dimensions because of the higher dielectric constant of silicon. In addition, the use of silicon provides for the potential of integration with silicon MMIC's and digital control circuits. Lastly, when compared with $\mathrm{GaAs}$, silicon wafers are available in much larger diameters and at lower cost thus facilitating integration of active devices, antenna and control circuits on a single wafer.

\section{ANTENNA DESIGN AND FABRICATION}

The antenna and the feed network are fabricated on a single 5000 to $10,000 \Omega$-cm silicon wafer. The thickness of the wafer is $0.381 \mathrm{~mm}$ with $\varepsilon_{\mathrm{r}}=11.7$. The thickness of the gold metalization is about $2.5 \mu \mathrm{m}$ which is about three times the skin depth at the center frequency $f_{o}$ of $6 \mathrm{GHz}$. This substrate has an effective thickness ratio (ref. 1) of 0.02 which is within the optimum range for high gain and low side lobes. Figure 1 shows a feed with electromagnetic coupling between a grounded CPW (GCPW) and slotline which are on opposite sides of a silicon wafer (ref. 6). At the GCPW input port, $Z_{o}$ is $50 \Omega$ while close to the transition to the slotline $Z_{0}$ is $60 \Omega$. The $Z_{o}$ of the slotline is $70 \Omega$. The distances $L_{s}$ and $L_{m}$ are $\sim \lambda_{g(\text { slotline) }} / 4$ and $\lambda_{\mathrm{g} \text { (microstrip) }} / 4$, respectively at $f_{0}$. The LTSA is formed by gradually flaring the width of the slotline by an angle $2 \alpha$. When $2 \alpha$ is close to 11 degrees a symmetric beam width is achieved for an antenna on Duroid (ref. 1). A symmetric beam results in high aperture efficiency if used for illuminating a reflector. The width $\mathrm{H}$ of the antenna is 
arbitrarily chosen as $0.3 \lambda_{\mathrm{g} \text { (slotline) }}$. The length $\mathrm{L}$ of the antenna as determined by $\alpha$ and $\mathrm{H}$ which is $1.5 \lambda_{\mathrm{g} \text { (slotline). }}$. Figure 2 shows a picture of the fabricated antenna.

\section{ANTENNA PERFORMANCE AND DISCUSSIONS}

The measured return loss $\left(\mathrm{S}_{11}\right)$ at the coaxial input port of the feed network is shown in figure 3 . The return loss is observed to be better than $-10 \mathrm{~dB}(2: 1$ VSWR) over a frequency range extending from 6 to $8 \mathrm{GHz}$. Although, the antenna has been designed at $6 \mathrm{GHz}$, the best return loss oceurs at about $7 \mathrm{GHz}$. This could be due to double side processing of the wafer which might have inadvertently offset the feed resulting in a shorter stub length. Typical measured $\mathrm{E}$ - and $\mathrm{H}$-plane radiation patterns are shown in figure 4 . The patterns are found to have good characteristics. The measured gain of the antenna is 5,7 , and $9 \mathrm{~dB}$ at 5,7 , and $9.4 \mathrm{GHz}$, respectively. Lastly, optimization of the LTSA on silicon has not been carried out and better performance might be expected with improvements.

\section{CONCLUSIONS}

The design and performance characteristics of a LTSA fabricated on high resistivity silicon wafer is presented. The LTSA exhibits good impedance match and radiation patterns.

\section{ACKNOWLEDGMENT}

The authors would like to thank Paul G. Young for the fabrication of the antenna.

\section{REFERENCES}

1. Yngvesson, K.S., et al.: The Tapered Slot Antenna - A New Integrated Element for Millimeter-Wave Applications. IEEE Trans. Microwave Theory Tech., vol. MTT-37, no. 2, Feb. 1989, pp. 365-374.

2. Yngvesson, K.S., et al.: Endfire Tapered Slot Antennas on Dielectric Substrates. IEEE Trans. Antennas Propagat., vol. AP-33, no. 12, Dec. 1985, pp. 1392-1399.

3. Nesic, A.: Endfire Slot Line Antennas Excited by a Coplanar Waveguide. IEEE Antennas and Propagation Society International Symposium Digest, vol. 2, IEEE, Piscataway, NJ, 1991, pp. 700-702.

4. Simons, R.N., et al.: New Techniques for Exciting Linearly Tapered Slot Antennas with Coplanar Waveguide. Electron. Lett., vol. 28, no. 7, Mar. 1992, pp. 620-621.

5. Rosen, A., et al.: Silicon as a Millimeter-Wave Monolithically Integrated Substrate - A New Look. RCA Rev., vol. 42, Dec. 1981, pp. 633-660.

6. Simons, R.N., et al.: Novel Coplanar Waveguide to Slotline Transition on High Resistivity Silicon. Electron. Lett., vol. 28, no. 24, Nov. 1992, pp. 2209-2210. 


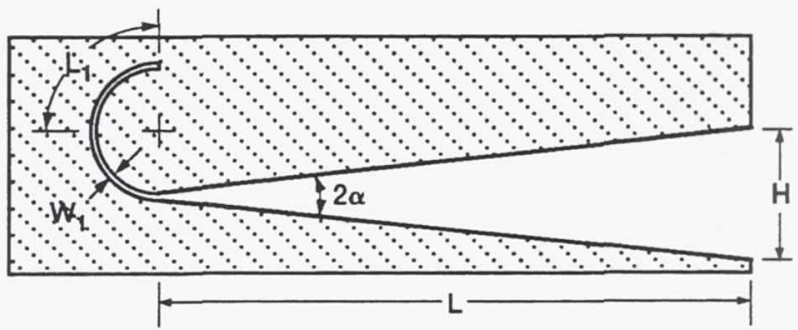

(a) Front side metalization.

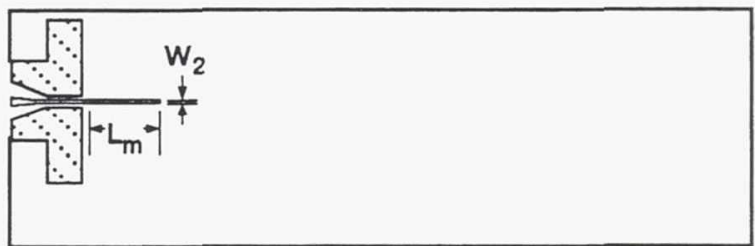

(b) Back side metalization.

Figure 1.-Schematic of the linearly tapered slot antenna. $\mathrm{W}_{\mathrm{s}}=0.16 \mathrm{~mm}, \mathrm{~W}_{\mathrm{m}}=0.15 \mathrm{~mm}$.

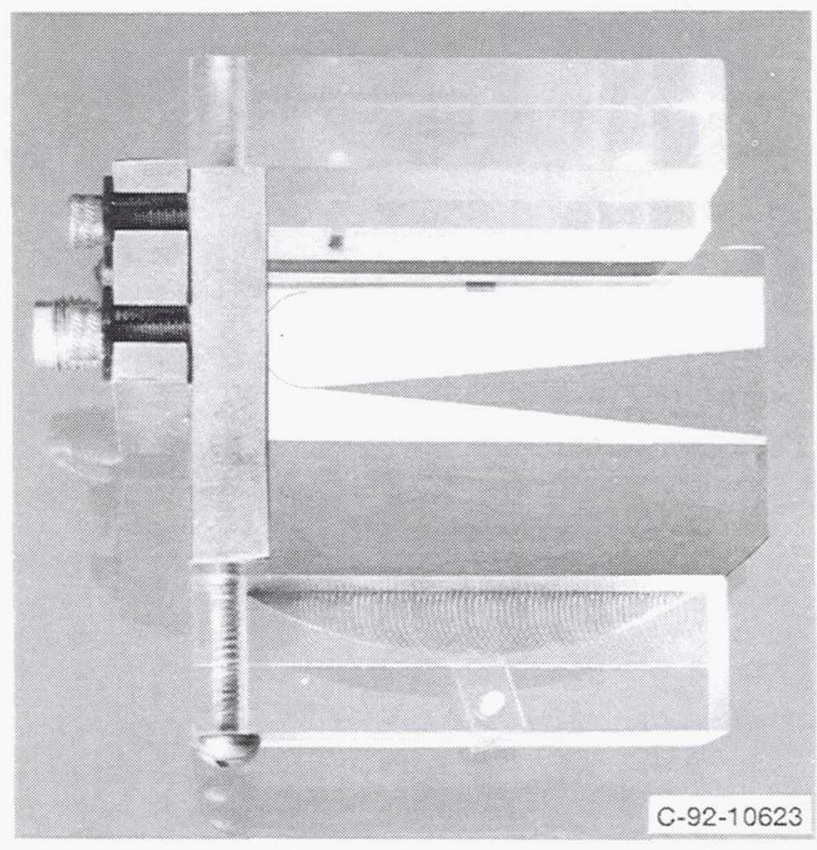

(a) Linearly Tapered Slot Antenna (LTSA) on silicon.

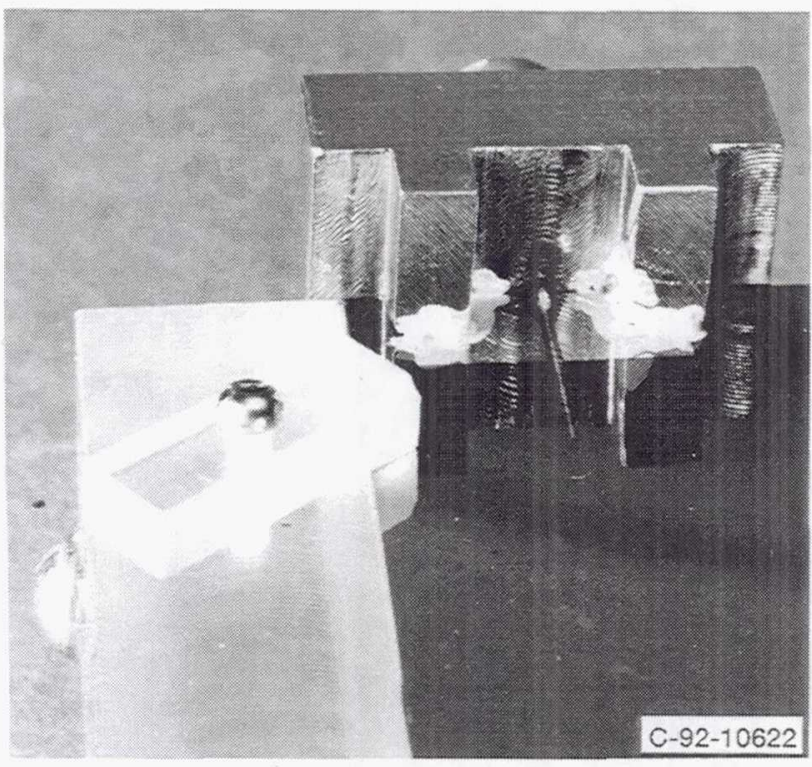

(b) Coplanar Waveguide Feed (CPW) for Linearly Tapered Slot Antenna on silicon.

Figure 2.-Photograph of the antenna. 


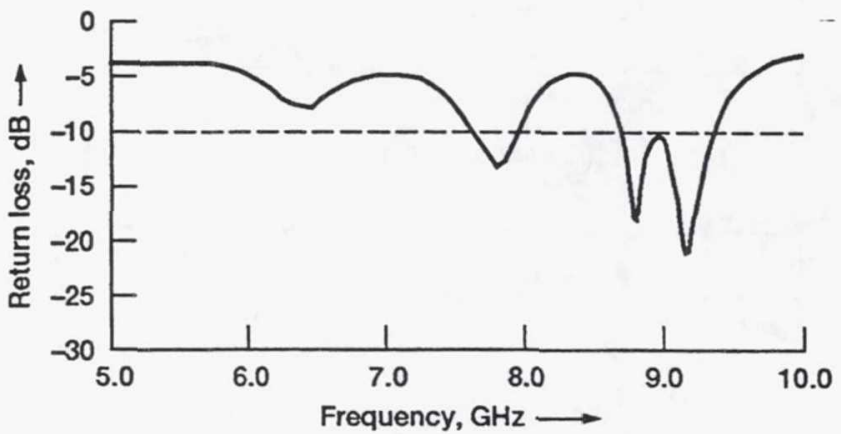

Figure 3.-Measured return loss $\left(S_{11}\right)$ at the coaxial input port.

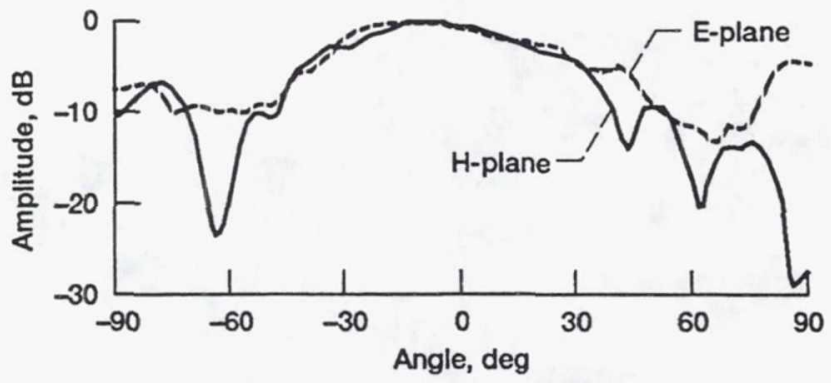

Figure 4.-Measured radiation pattern of the LTSA at $7 \mathrm{GHz}$. 
Public reporting burden for this collection of information is estimated to average 1 hour per response, including the time for reviewing instructions, searching existing data sources, gathering and maintaining the data needed, and completing and reviewing the collection of information. Sen ashington Headquarters Services, Directorate for in Davis Highway, Suite 1204, Arlington, VA 22202-4302, and to the Office of Management and Budget, Paperwork Reduction Project (0704-0188), Washington, DC 20503.

\begin{tabular}{|l|l|l}
\hline 1. AGENCY USE ONLY (Leave blank) & $\begin{array}{c}\text { 2. REPORT DATE } \\
\text { March } 1993\end{array}$ & $\begin{array}{r}\text { 3. REPORT TYPE AND DATES COVERED } \\
\text { Technical Paper }\end{array}$
\end{tabular}

4. TITLE AND SUBTITLE

Characteristics of Linearly Tapered Slot Antenna With CPW Feed on High Resistivity Silicon

6. AUTHOR(S)

Rainee N. Simons, Susan R. Taub, and Richard Q. Lee
5. FUNDING NUMBERS

WU-506-44-2C

\section{PERFORMING ORGANIZATION NAME(S) AND ADDRESS(ES)}

Sverdrup Technology, Inc.

Lewis Research Center Group

2001 Aerospace Parkway

Brook Park, Ohio 44142
8. PERFORMING ORGANIZATION REPORT NUMBER

E-7658

9. SPONSORING/MONITORING AGENCY NAMES(S) AND ADDRESS(ES)

National Aeronautics and Space Administration

Lewis Research Center

Cleveland, Ohio 44135-3191

10. SPONSORING/MONITORING AGENCY REPORT NUMBER

NASA TM-106057

11. SUPPLEMENTARY NOTES

Prepared for the 1993 IEEE AP-S International Symposium and URSI Radio Science Meeting, sponsored by the IEEE and USNC Commissions A, B, D, and F, Ann Arbor, Michigan, June 27-July 2, 1993. Rainee N. Simons, Sverdrup Technology, Inc., Lewis Research Center Group, 2001

Aerospace Parkway, Brook Park, Ohio 44142, Susan R. Taub, and Richard Q. Lee, NASA Lewis Research Center. Responsible person, Rainee N. Simons, (216) 433-3462.

\begin{tabular}{|l|l}
\hline 12a. DISTRIBUTION/AVAILABILITY STATEMENT & 12b. DISTRIBUTION CODE
\end{tabular}

Unclassified - Unlimited

Subject Category 33

13. ABSTRACT (Maximum 200 words)

A linearly tapered slot antenna (LTSA) has been fabricated on a high resistivity silicon substrate and tested at C-Band frequencies. The LTSA is electromagnetically coupled to a coplanar waveguide (CPW) feed. In this paper, the measured radiation patterns, gain and return loss are presented and discussed.

\section{SUBJECT TERMS}

Silicon; Coplanar waveguide; Linearly tapered slot antenna; Array antenna

15. NUMBER OF PAGES

6

16. PRICE CODE

\section{$\mathrm{A} 02$}

OF REPORT

Unclassified
18. SECURITY CLASSIFICATION OF THIS PAGE

Unclassified
19. SECURITY CLASSIFICATION OF ABSTRACT

Unclassified 